\title{
Student perceptions of difficulties in second language writing
}

\author{
Nuray Okumuş Ceylan ${ }^{\mathrm{a}} *$ (iD) \\ APA Citation: \\ ${ }^{a}$ Bülent Ecevit University, Zonguldak, Turkey ${ }^{b}$ \\ Ceylan, O. N. (2019). Student Perceptions of Difficulties in Second Language Writing n. Journal of Language and Linguistic Studies, 15(1), \\ 151-157. \\ Submission Date:22/06/2018 \\ Acceptance Date:19/01/2019
}

\begin{abstract}
Among the four language skills, writing is considered as the most challenging and difficult skill for most of the foreign language learners (Reid, 2002). Moreover, the development of students' L2 writing can be influenced by multiple factors such as L1 writing ability, L2 proficiency, and writing experiences in both languages (Kobayashi \& Rinnert, 2008; Kubota, 1998). The starting point of this study was the difficulties students face in their writing process observed during the in-class writing tasks (Kobayashi \& Rinnert, 2008; Kubota, 1998). This study aims to find out students' perceptions of difficulties they come across during their writing process in Writing Skills I-II courses in which they are supposed to write academic paragraphs and essays.
\end{abstract}

(C) 2019 JLLS and the Authors - Published by JLLS.

Keywords: second/ foreign language writing; academic writing; difficulties in writing process

\section{Introduction}

Among the four language skills, writing is considered as the most challenging and difficult skill for most of the foreign language learners (Reid, 2002). The development of students' L2 writing can be influenced by multiple factors such as L1 writing ability, L2 proficiency, and writing experiences in both languages (Kobayashi \& Rinnert, 2008; Kubota, 1998). The starting point of this study was the difficulties students face in their writing process observed during in-class writing tasks. The main goal of the relevant writing course is to develop writing competence in which students are expected to produce a well-structured piece of writing. It is a process in which students create ideas, organize them and write them in a unified form. The students studying at Bülent Ecevit University English Language and Literature Department take obligatory Writing Skills I and II courses. They are supposed to write academic paragraphs and essays. The starting point for this study was the individual observations of the instructors that indicated few but not most of the students could express their ideas well in paragraphs or essays, and also these few students could give well-written exam papers in the other courses where they were supposed to analyze the literary products and express their own ideas. Thus, this study aims to find out students' perceptions of difficulties they come across during their writing process in which they are supposed to write academic paragraphs and essays to understand why few but not most of the students could not write well.

"Corresponding author. Tel.: +90 37202911100

E-mail address: nurayokumus@beun.edu.tr 


\subsection{Literature review}

As the literature states, students face difficulties due to several reasons such as transcribing ideas, structuring them, focusing on accuracy and misinterpreting the instructions. For example, Hasewaga (2013) found out that what students perceive themselves to be doing in terms of their writing does not appear to represent what they are actually doing in their written work. Evans and Green (2007) found that students perceived language related components of academic writing to be more difficult than structure/ content-related components. The former type includes difficulties in communicating ideas 'appropriately', 'accurately' and 'smoothly', while the latter type includes 'writing the method sections', 'writing references', and 'writing results section'. This is supported by the results of Bitchener and Basturkmen (2006) and Dalsky and Tajino (2007), in which students experienced problems and difficulties in organizing ideas and arguments, using appropriate styles of writing, and expressing thoughts clearly in English.

On the other hand, other studies (Marshall, 1991; Kubota, 1998) have demonstrated different results. Marshall (1991), for example, suggests that students may have difficulties with the structure of a paper more often than the language-related components. Kubota (1998) suggests that L2 writing difficulties may be caused by teachers' instructional emphasis on accuracy at the sentence-level rather than on discourse organization. Hasewaga (2013) identifies several possible factors that contribute to this tendency. Firstly, they fail to transcribe their ideas and conceptualizations into writing in the form of notes or material they may draw upon when composing their essay. Secondly, they may lack sufficient explanation of the specialized vocabulary items such as 'thesis statement' or 'topic sentence'. Lastly, these items may be misinterpreted by students in various ways depending on their contexts.

Asadifard and Koosha (2013) found that there is a high degree of reluctance among students towards writing activities; they are perhaps among their last choices, or they try not to engage themselves in writing unless they have to. Also, they stated that when the students feel their works may not be thoroughly checked, they gradually lose their interest in writing hence reluctance may be the outcome. The results suggested that the students have difficulty in interpreting written feedback. Ismail (2010) stated that students were satisfied with their writing skills; however, they still need to pay attention to this skill. Also, he stated that first language influence and cultural patterns of L1 should be taken into consideration during writing classes as the use of L1 may enhance better writing performance in L2.

According to Scarcella (2002), a clearly written English text provides essential input for writing development, particularly citations, references, coherence, and cohesion. Therefore, it is a dependable source of academic English input in light of Chinese EFL writers. English learners can benefit from the form, format, and organization of the English text. Besides, the clearly written text is supposed to establish a strong relationship between the author and readers through its logical cohesion.

\section{Method}

Since different results or claims are available for L2 learners' writing difficulties in the literature Kubota, 1998; Marshall, 1991; Bitchener and Basturkmen, 2006; Dalsky and Tajino, 2007, Evans and Green, 2007), the aim of this study is to find out perceptions of Bülent Ecevit University English Language and Literature department first year students' on the difficulties they face in Writing Skills III courses in which they were expected to write paragraphs and essays. 


\subsection{Instrument}

The quantitative data was gathered via a questionnaire prepared by the researcher including items referring to the difficulties students face in writing.

\subsection{Data collection procedures}

The quantitative data was gathered at the end of the 2016- 2017 education year after they have taken the Writing Skills I- II courses. They were expected to write paragraphs and essays, and in this process they faced certain difficulties.

\subsection{Data analysis}

The data was analyzed using SPSS, Frequency tests.

\section{Results and Discussion}

The item with the highest percentage is that most of the students do not write because they think they will not need such writing in future. Moreover, they are not interested in the topics. As Asadifard and Koosha (2013) suggest, the results also suggest and support that they are not willing to write due to their prior negative experiences with writing tasks; thus, they need encouragement provided by the teacher since they reported that they feel a lack of appropriate interpersonal relationships between their teacher and themselves. Thus, they believe they do not have adequate writing activities to encourage them to write. Teachers should include in-class writing to encourage them to practice their writing skill and guide them with their feedback. Also, teacher may have writing interviews with students since they might interpret the feedback on their papers, oral feedback might provide better comprehension of strengths and weaknesses.

The results indicate that the students lack basic writing strategies such as such as pre-writing, drafting, editing and setting goals when they start to write. The findings suggest that students need to be trained on writing strategies. The training may teach them to start writing to overcome the stressful process of writing. Moreover, students perceived language- related components of academic writing to be more difficult than structure/ content-related components. As Lee and Tajino (2008) also suggest and support, many students claimed a high degree of difficulty with their learning tasks because they had limited knowledge of academic writing. 
Table 1. Frequency test results of the questionnaire

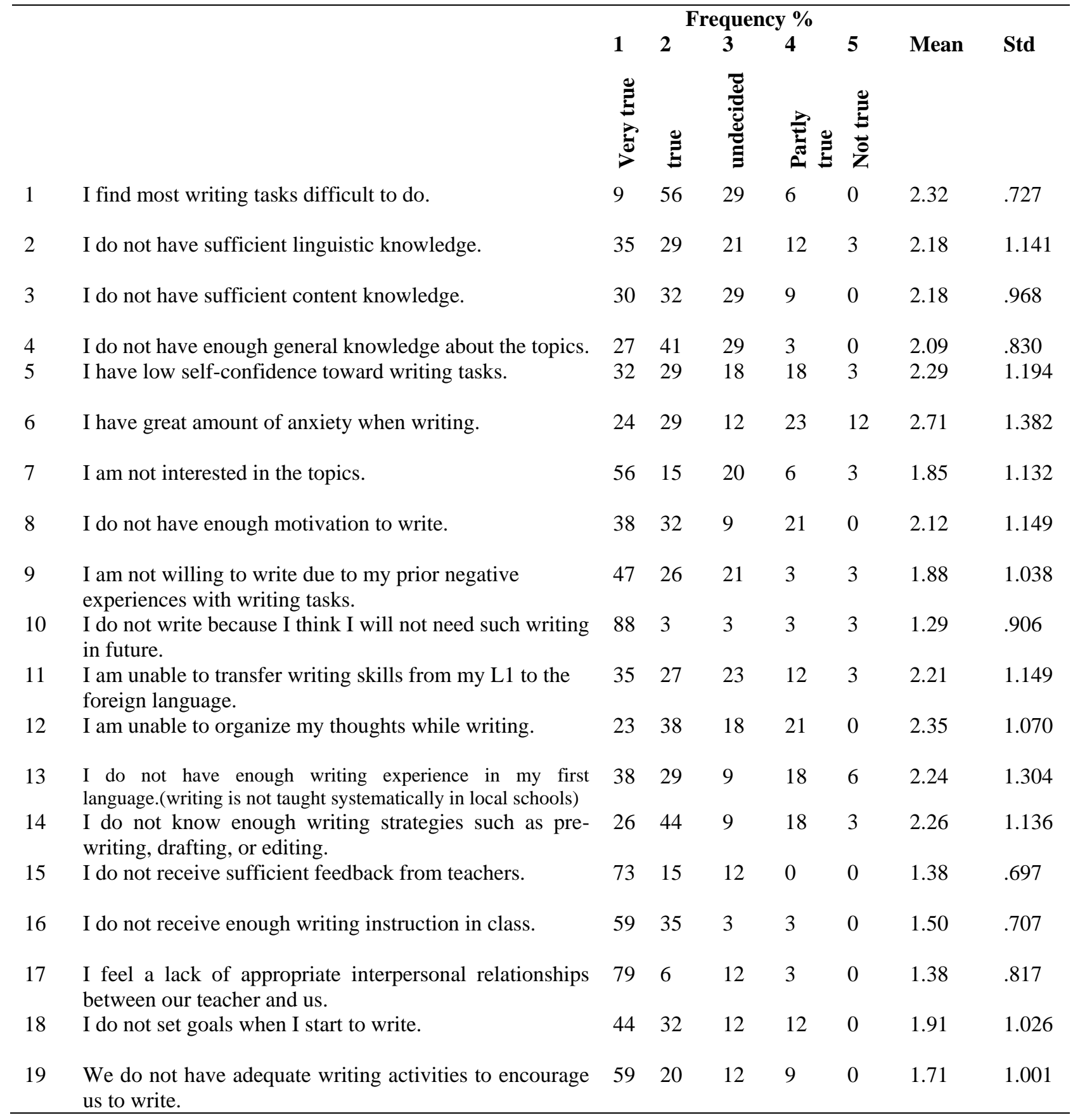

If the students do not believe in the benefit of the work they are doing and they are not interested in the topics, they may not want to proceed in that route. This is an important issue and may be the subject of a further study since it may cause demotivation towards writing and writing courses.

Basic writing strategies such as such as pre-writing, drafting, editing and setting goals when they start to write may help them to focus on a goal, brainstorm ideas, organize them and write in a unified form. The fact that they do not have enough general knowledge about the topics suggests that they lack basic research skills necessary for a university level student. 
The fact that they believe they do not receive enough writing instruction in class may explain why they believe most writing tasks are difficult to do for more than half of the students. It is a thought provoking result since in writing course rather than teaching concrete subjects like grammatical patterns, the teachers guide the students with basic information on the structure of a paragraph or an essay, show some samples, make them write and give feedback on what they write. Thus, what students expect from writing instruction is an issue to be considered further. They also stated that they do not receive sufficient feedback from teachers.

\section{Conclusions}

A further question can be the type of feedback provided to the students; oral or written, since as the literature states (Hasewaga, 2013) the students may misinterpret written feedback, but may ask further questions to the teacher to confirm or fully understand if oral feedback is provided.

Moreover, to be a good writer they should be good readers of academic English. Through reading academic English, firstly, they should understand deeply what is expected from them. Secondly, they should gain familiarity to the common expressions and the vocabulary. Moreover, they should see samples of expressing ideas through linkers, transitions between the sections. As Scarcella (2002) indicates, a clearly written English text provides essential input for writing development, particularly citations, references, coherence, and cohesion. Therefore, it is a dependable source of academic English input in light of Chinese EFL writers. English learners can benefit from the form, format, and organization of the English text. Besides, the clearly written text is supposed to establish a strong relationship between the author and readers through its logical cohesion.

\section{Limitations and Pedagogical Implications}

The conclusion of this research is limited to the participants and setting. The participants who participated to this research were only English Language and Literature department first year students'.

\section{Recommendations}

Learning how to write good academic essays is an important skill that requires practice and reading academic English. The type of feedback provided to the students should be both oral and written , since the students may misinterpret written feedback, but may ask further questions to the teacher to confirm or fully understand if oral feedback is provided.

\section{References}

Asadifard, A. \& Koosha, M. (2013). EFL Instructors and Student Writers' Perceptions on Academic Writing Reluctance, Theory and Practice in Language Studies, 3(9), 1572- 1578.

Bitchener, J. \& Basturkmen, H. (2006). Perceptions of difficulties of postgraduate L2 thesis students writing the discussion section. Journal of English for Academic Purposes, 5 (1), 4-18. 
Curry, M, J., \& Hewings, A. (2003). Approaches to teaching writing. In C. Coffin, M. J.Curry,S.Goodman, A. Hewings,T.M. Lillis \&J.Swann (Eds), Teaching academic writing (pp.19 - 44). London, UK:Routledge

Dalsky, D. \& Tajino, A. (2007). Students' perceptions of difficulties with academic writing: A report from Kyoto University academic writing courses. Kyoto University Researches in Higher Education, 13, 45- 50.

Evans, S. \& Green, C. (2007). Why EAP is necessary: A survey of Hong Kong tertiary students. Journal of English for Academic Purposes, 6 (1), 3-17.

Grabe, W. (2001). Notes toward a theory of second languge writing. In Silva, T. And Matsuda, P.K. (Eds). On second language writing, 39-57. New Jersey; Lawrence Erlbaum Associates Inc., Publishers.

Hasegawa, H. (2013). Students' perceptions and Performances in Academic Essay Writing in Higher Education, International Journal of Innovative Interdisciplinary Research, 4.

Ismail, S. A. A.(2010). Exploring Students' Perceptions of ESL Writing. English Language Teaching, $4(2)$.

Kubota, R. (1998). An investigation of L1-L2 transfer in writing among Japanese university students: Implications for contrastive rhetoric. Journal of Second Language Writing. 7 (1), 69-100.

Kuboyashi, H. \& Rinnert, C. (2008). Task response and text constrcution across L1 and L2 writing. Journal of Second Language Writing, 17 (1), 7-29.

Lee, S. N. \& Tajino, A. (2008). Understanding Students' Perceptions of Difficulty with Academic Writing for Teacher Development: A Case Study of the University of Tokyo Writing Program. Kyoto University Research Information Repository. Retrieved on 20th December, 2015 from http://repository.kulib.kyoto-u.ac.jp/dspace/handle/2433/70833

Marshall, S. (1991). A genre-based approach to the teaching of report-writing. English for Spesicif Purposes. 10(1), 3-43.

Nauman, A.D. et al., (2011. What makes writing good? An essential question for teachers. The reading Teacher 64(5), 318-328.

Petric, B.\& Czarl, B. (2003). Validating a writing strategy questionnaire. System, 131, 187- 215.

Reid, J. (2002). Writing. In Ronald Carter and David Nunan (eds). The Cambridge guide to teaching English to speakers of other languages (pp. 28-33). Cambridge; Cambridge University Press.

Scarcella, R. (2002). Some key factors affecting English learners' development of advanced literacy. In M. J. Schleppegrell \& M. C. Colombi (Eds.), Developing advanced literacy in first and second language (pp. 209-226). Mahwah, NJ: Lawrence Erlbaum Associates. 


\section{Öğrencilerin ikinci dilde yazma becerisinde karşılaştıkları sorunlarla ilgili düşünceleri}

$\ddot{O} \mathbf{z}$

Dört dil becerisi arasında yazma birçok dil öğrencisi için en zor ve meydan okuyan olarak bilinir (Reid, 2002). Öğrencilerin yabancı dilde yazma becerilerini geliştirmek ana dilde yazma becerisi, yabancı dil düzeyive her iki dilde yazma tecrübesi gibi birçok etkene bağlıdır. Bu çalışmanın başlangıç noktası öğrencilerin Yazma Becerisi III derslerinde yapılan sınıf-içi yazma çalışmaları sırasında karşılaştıkları zorluklarla ilgili tutumlarını belirlemektir.

Anahtar sözcükler: ikinci/ yabancı dilde yazma; akademik yazma; yazma sürecindeki zorluklar

\section{AUTHOR BIODATA}

Nuray Okumuş Ceylan received her BA and PhD degree in English Teaching Department from Gazi U. and MA

from Bilkent U. MATEFL program. She worked English prep schools of Karaelmas U. and Kocaeli U. She is currently working as an Associate Professor in English Language and Literature Department in Bulent Ecevit U. 